\title{
Evidences of inclined transpression at the contact between Vinjamuru group and Udayagiri group of Nellore Schist Belt, Andhra Pradesh, India
}

\author{
Sankha Das ${ }^{1, *}$, Devasheesh Shukla ${ }^{1}$ and S K Mitra ${ }^{2}$ \\ ${ }^{1}$ Specialised Thematic Mapping, SU: T and AP, Geological Survey of India, \\ Bandalaguda, 500 068, India. \\ ${ }^{2}$ Geological Survey Of India, 284/1A, NSC Bose Road, Kolkata 700 047, India. \\ *Corresponding author.e-mail: sankhad56@gmail.com
}

The Nellore Schist Belt (NSB) is a curvilinear Archaean schist belt, approximately $350 \mathrm{~km}$ long and 8-50 km wide. The Nellore Schist Belt is considered to be Neoarchean in age and stratigraphically NSB is classified as the western Udayagiri group (dominated by metasediments) and underlying eastern Vinjamuru group (dominated by metabasalts). There is a long controversy regarding the contact relationship between Udayagiri and Vinjamuru groups. Earlier researchers regarded the contact between two groups as tectonic on the basis of metamorphism. A shear zone and a possible thrust contact between the two groups have also been reported. On the basis of present study, an NNW-SSE trending, westerly dipping inclined transpressional zone is found at the contact between Udayagiri and Vinjamuru groups in the central western part of the NSB. Kinematic analysis of both the hanging wall and foot wall of the westerly dipping thrust zone shows presence of strong S1 schistosity, shear bands and S-C fabric in both strike and dip section along with east-verging overturned fold, westerly dipping inverted beds, suggesting partitioning of non-coaxial deformation in strike-slip and dip-slip component along with a pure shear component. Strike-slip is more prominent in the northern part of the contact than the southern part. The presence of steep to moderate northerly plunging non-orthogonal stretching/mineral elongation lineation all along the contact and clockwise shift of plot of the same in stereo net from its orthogonal position and presence of other kinematic indicators in plan suggests a right lateral strike-slip component. As a whole, it is suggested that Udayagiri group is thrusted over Vinjamuru group along a westerly dipping thrust plane with a right lateral strike-slip motion and simultaneous E-W contraction.

\section{Introduction}

Transpressional zones are a common feature of areas of oblique tectonic convergence characterised mostly by vertical shear zone boundaries and stretching lineations. Simple transpression has been defined by Harland (1971) as two rigid blocks approaching each other obliquely. Sanderson and
Marchini (1984) defined transpression as simultaneous simple and pure shear along horizontal $\mathrm{X}$ and $Y$ reference coordinate axes respectively and extension along vertical Z-coordinate axis to accommodate the shortening, assuming no extrusion along X-coordinate axis (figure 1 of Sanderson and Marchini 1984). Fossen and Tikoff (1993) defined transpression, as a combination of simple shear

Keywords. Nellore Schist belt; Udayagiri group; Vinjamuru group; inclined transpression. 
and an orthogonal pure shear, which results in a non-plane strain deformation. Fossen and Tikoff (1998) accommodated extensions along both the horizontal-X and vertical-Z reference coordinate axes (figure 2 of Fossen and Tikoff 1998) and defined five categories of transpressional deformation depending on the angle of convergence, and discussed in detail the state of finite strain and orientation of stretching lineation for different categories. The bulk strain can be of the flattening or constrictional type and the pitch of stretching lineation can vary from horizontal to vertical, depending on the angle of oblique convergence (Fossen and Tikoff 1998). Simple shear parallel to any of the reference coordinate axes, will create monoclinic strain symmetry, but if the simple shear is oblique, i.e., not parallel to any of the reference coordinate axes, then it will create triclinic strain symmetry. Transpressional deformation in a ductile shear zone involves simple shear, parallel to shear zone walls and a simultaneous orthogonal pure shear across the shear zone walls (Sengupta and Ghosh 2004). In a non-extrusive transpressoinal zone, the stretching lineation can be parallel to the external $\mathrm{X}$-coordinate direction or Z-coordinate direction (figure 1 of Sengupta and Ghosh 2004) depending on, whether the zone is simple shear dominated or pure shear dominated. Sengupta and Ghosh (2004) defined two parameters a and $\mathrm{b}$ (ratio of strain rate of pure shear, along $\mathrm{X}$ and $\mathrm{Y}$ coordinate axes, with strain rate of simple shear) and defined four cases of transpressional deformation (depending on the values of $a$ and $b$ ) that produce transport parallel or vorticity parallel stretching lineation, both in case of bulk flattening and bulk constrictional deformation, which can be distributed into nine (I-IX) groups (figure 3 of Sengupta and Ghosh 2004). Inclined transpression is described within inclined boundary zones (non-vertical shear zones) where the non-coaxial strain is partitioned into strike-slip and dip-slip components, parallel to Xc and $\mathrm{Zc}$ reference coordinate axes respectively (figure 1 of Jones et al. 2004), along with simultaneous contraction. In the case of inclined transpression, the orientation of all three axes of a Finite Strain Ellipsoid (FSE) will vary throughout the deformation and the pitch of stretching lineation on a foliation plane will vary from $0^{\circ}$ to $90^{\circ}$ along the zone (Jones et al. 2004). In inclined transpressional zones, the strain is generally of flattening type (Jones et al. 2004). Strain patterns can be heterogeneous along and across an inclined transpressional shear zone and different parts of the shear zone may show different structures or dominance of certain type of structures, depending on whether that part is dominated by strike-slip, dip slip or compression. The present study finds evidences of inclined transpression at the contact between
Udayagiri and Vinjamuru group of NSB, which is the main focus of this paper.

\section{Geological setting}

The Nellore Schist Belt (NSB) is a curvilinear schist belt with neo-Archean and younger rocks, extending approximately over a strike length of $350 \mathrm{~km}$ long along its $\mathrm{N}-\mathrm{S}$ strike and is about $8-50 \mathrm{~km}$ wide. The NSB is thrust over the Nallamalai Fold Belt (NFB) on its west, and the Eastern Ghat Mobile Belt (EGMB) is thrust over NSB on its eastern margin. Saha et al. (2010) have described a thrusted contact and inclined transpression between NSB and NFB. The author suggests top towards west shear on stratum parallel sub-horizontal detachment on an easterly-dipping thrust with a left lateral strike slip component subparallel to the overall $\mathrm{N}-\mathrm{S}$ trend of Nallamalai fold belt along with a simultaneous E-W shortening. In most of the cases, plots of stretching lineation show an anticlockwise shift from its orthogonal position (Saha et al. 2010). The Nellore Schist Belt (NSB) is considered to be equivalent of the Sargur group with a protolith age of 3.3-2.5 Ga (Hari Prasad et al. 1999). Metabasalt of Vinjamuru group (from Chaganam and Chundi) of NSB is dated to be $2654 \pm 100 \mathrm{Ma}$ from $\mathrm{Sm}-\mathrm{Nd}$ systematics, which is considered the preferred time of the formation of these volcanics, and an Sm-Nd age of $1911 \pm 88 \mathrm{Ma}$ is obtained from the differentiated gabbros intrusive into NSB (Ravikant 2010).

Stratigraphically the NSB is divided into (upper?) western Udayagiri group/domain and (lower?) eastern Vinjamuru group/domain (Ramam and Murty 1997; Dobmeier and Raith 2003). However, subsequently (Saha et al. 2013) NSB has been divided into four tectonic units, viz., the Vinjamuru group, the Kandra complex, the Kanigiri complex and the Udayagiri group from bottom to top. The Udayagiri group consists mainly of psammite with minor conglomerate and pelite locally intercalated with felsic volcanic rocks and relatively rare basalts and limestones which have undergone greenschist facies of metamorphism. The Vinjamuru group is dominated by metabasalt intercalated with psammopelitic schist, quartzites, gneisses and migmatites and locally abundant felsic metavolcanics, marbles, calcsilicate gneisses and kyanite-sillimanite schist of amphibolite facies (Vasudevan and Rao 1975; Narayana Rao 1983; Ramam and Murty 1997). However, the exact stratigraphic disposition and nature of contact between the above two groups are debated (Ramam and Murty 1997) (figure 1). On the basis of metamorphism, the contact between the Vinjamuru group and the Udayagiri group has been described as tectonic 


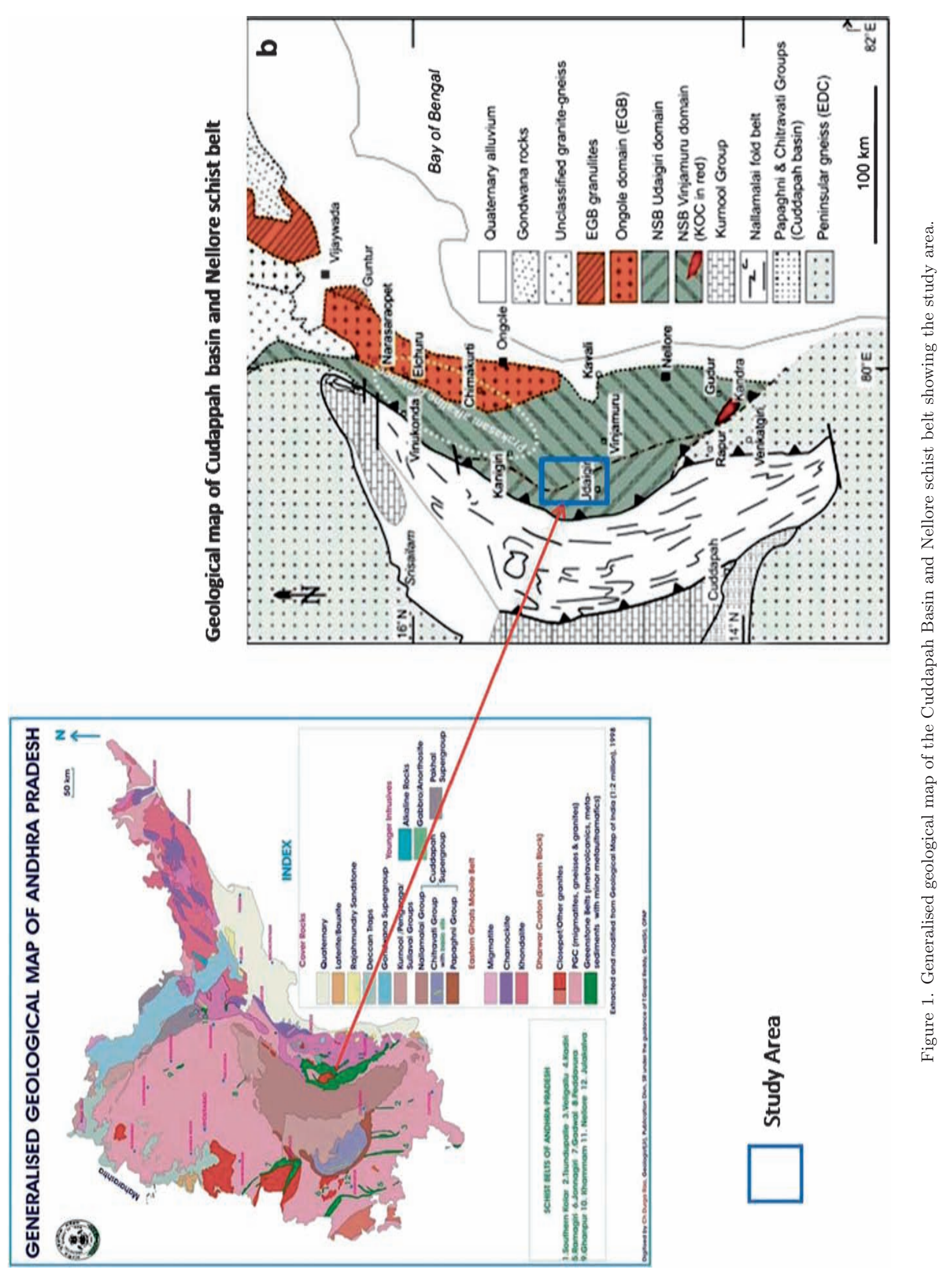


GEOLOGICAL MAP OF CENTRAL WESTERN PART OF NSB, PARTS OF TOPOSHEET NO.

57M/4 AND 57M/8, 57N/1 and N/5, NELLORE AND PRAKASAM DISTRICTS, ANDHRA PRADESH

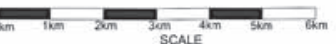

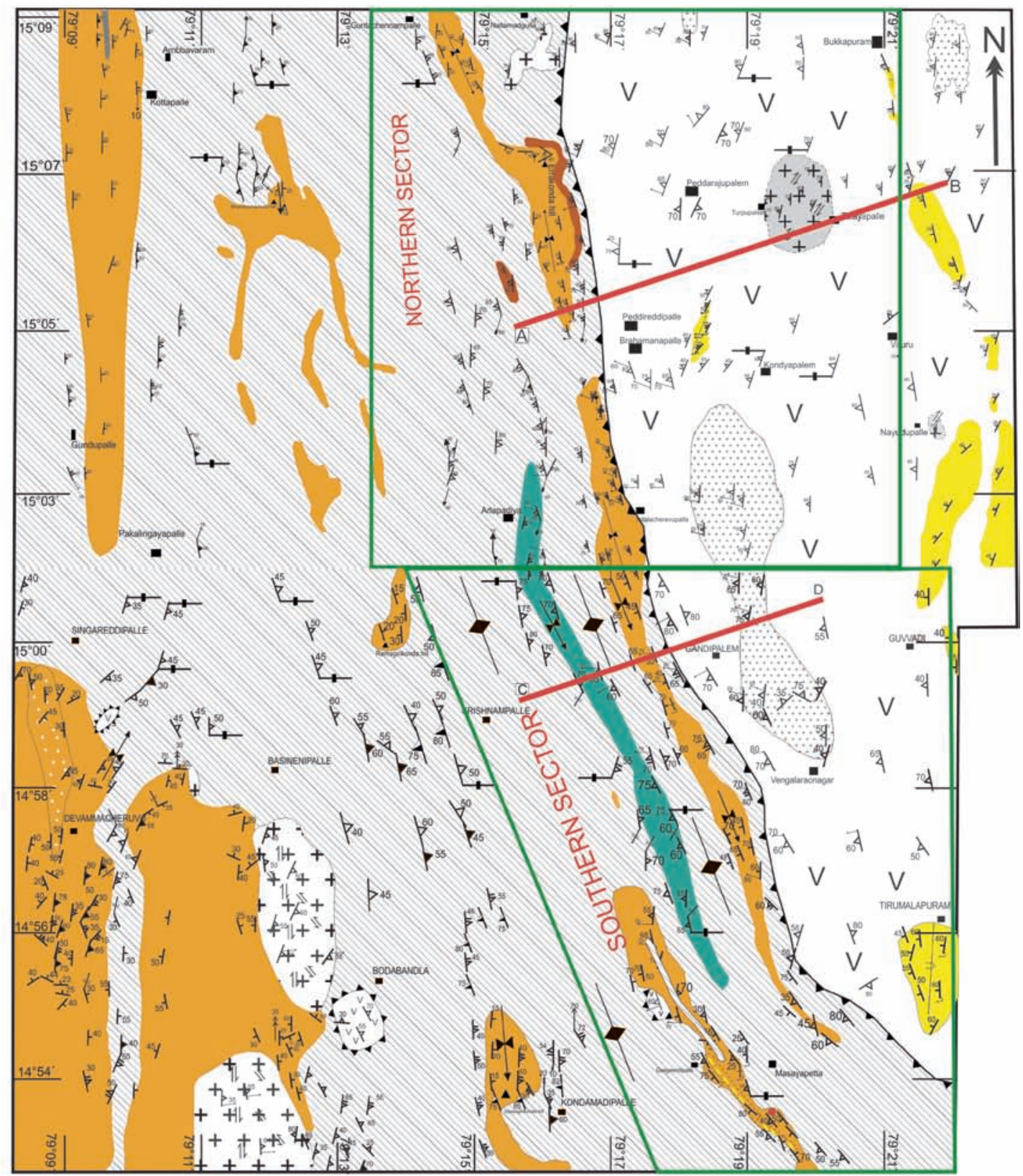

INDEX

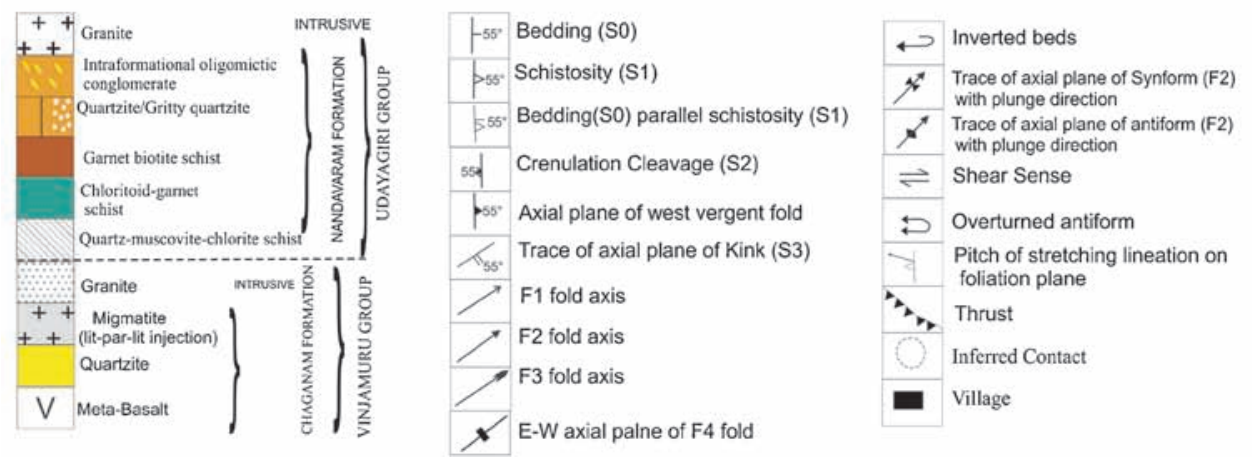

Figure 2. Geological map of the study area. 
(Moeen 1998). Vasudevan et al. (1975) (GSI unpublished report) reported a shear zone between the two groups of rocks and a possible thrust contact between them. An easterly dipping thrust at the contact between Vinjamuru group and Udayagiri group has been ruled out, as the foliation here shows a steep westerly dip in rocks of both groups at the contact (Saha 2004). So far, no conclusive literature exists describing the exact nature of the contact between Udayagiri and Vinjamuru group on the basis of both structure and metamorphism.

\section{Present work}

The present study was confined to the central western part of the Nellore Schist Belt (figure 1) in parts of Nellore and Prakasam district, Andhra Pradesh, India. In the present study area, the Vinjamur group mainly comprises metabasalt/amphibolites, lit-par-lit injection migmatite, quartzite and intrusive granite exposed mainly in eastern part of the study area (figure 2). The Udayagiri group mainly comprises of the quartz-muscovite-chlorite schist, garnet-biotite schist, chloritoid-garnet-schist, quartzite and younger intrusive granite (figure 2). The highest grade of metamorphism in the Udayagiri group is upper greenschist facies and in Vinjamuru group is upper amphibolite facies.

In the Nellore schist Belt, the previous researchers describe mainly three phases of structures. The first generation folds (F1) are isoclinal to reclined type. The F1 folds show strong variation in plunge amount varying from $0^{\circ}$ to $90^{\circ}$ (figure $3 \mathrm{a}$ ) and direction (either towards north or south). The D1 deformation has given rise to pervasive S1 schistosity, with strike varying from NNW-SSE to N-S and NNE-SSW, with the moderate to steep dip on either side (either east or west) which indicates the folding nature (F2) of the rocks (figure 3b). The second generation of deformation has resulted in pervasive major to minor scale crenulations with well-developed crenulation cleavage (S2), trending NNW-SSE with vertical to sub-vertical dips towards the west (figure 3c). This deformation has given rise to map scale (F2) antiforms and synforms (figures 2, 3d, e) with shallow plunge either towards north or south. At places, the F2 folds are coaxial with F1 folds and given rise to the hookshaped Type-3 interference pattern of Ramsay. The last generation of deformation is represented by E-W and NW-SE trending cross folds (Suresh et al. 2006, GSI unpublished report; Srinivasan and Roop Kumar 1995, GSI unpublished report). The aim of this paper is to decipher the nature of the contact between Udayagiri group and Vinjamuru group by analyzing the deformation styles near the
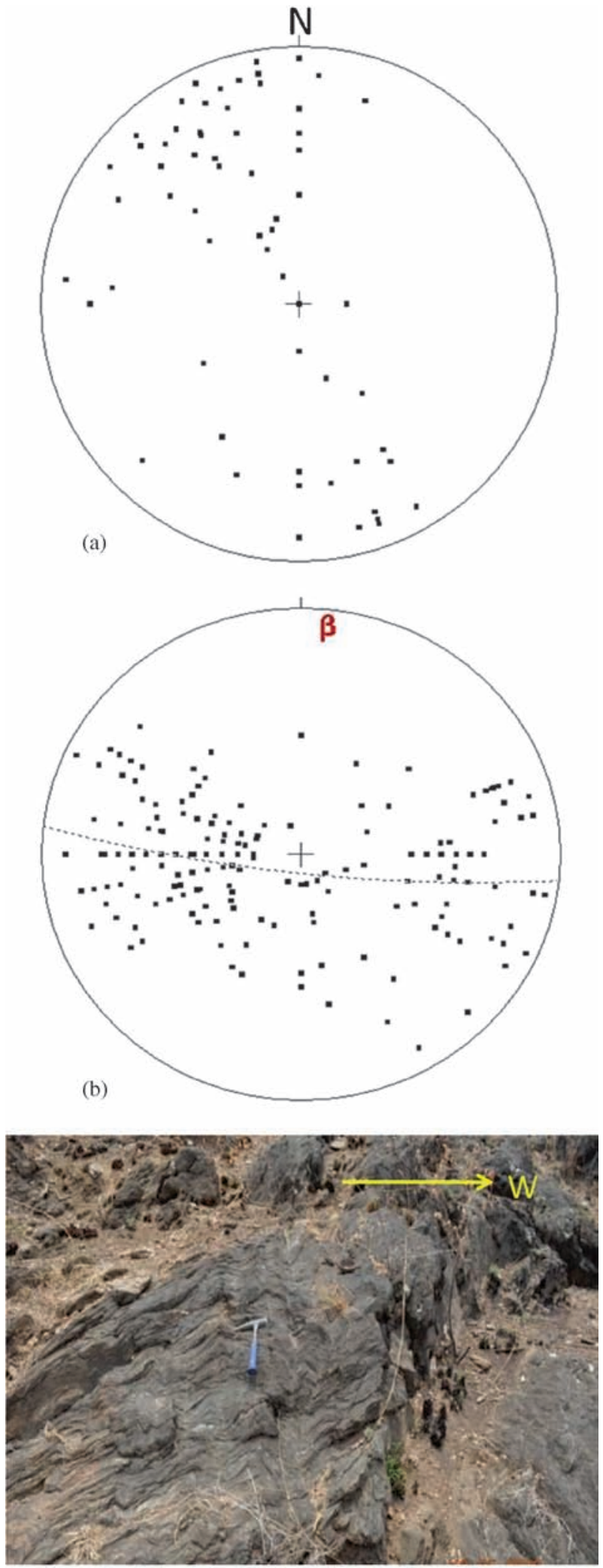

(c)

Figure 3. (a) Plots of plunge of F1 fold axis. (b) Lower hemisphere plots of poles of S1 schistosity of whole Udayagir group. $\mathrm{N}=249$, calculated $\beta$ axis $6-006$. The poles show girdle distribution due to F2 folding. (c) F2 folds in metapelite of Udayagiri group (profile section). (d) Cross-section along line $\mathrm{A}-\mathrm{B}$ marked in figure 2. (e) Cross-section along line $\mathrm{C}-\mathrm{D}$ marked in figure 2 . 

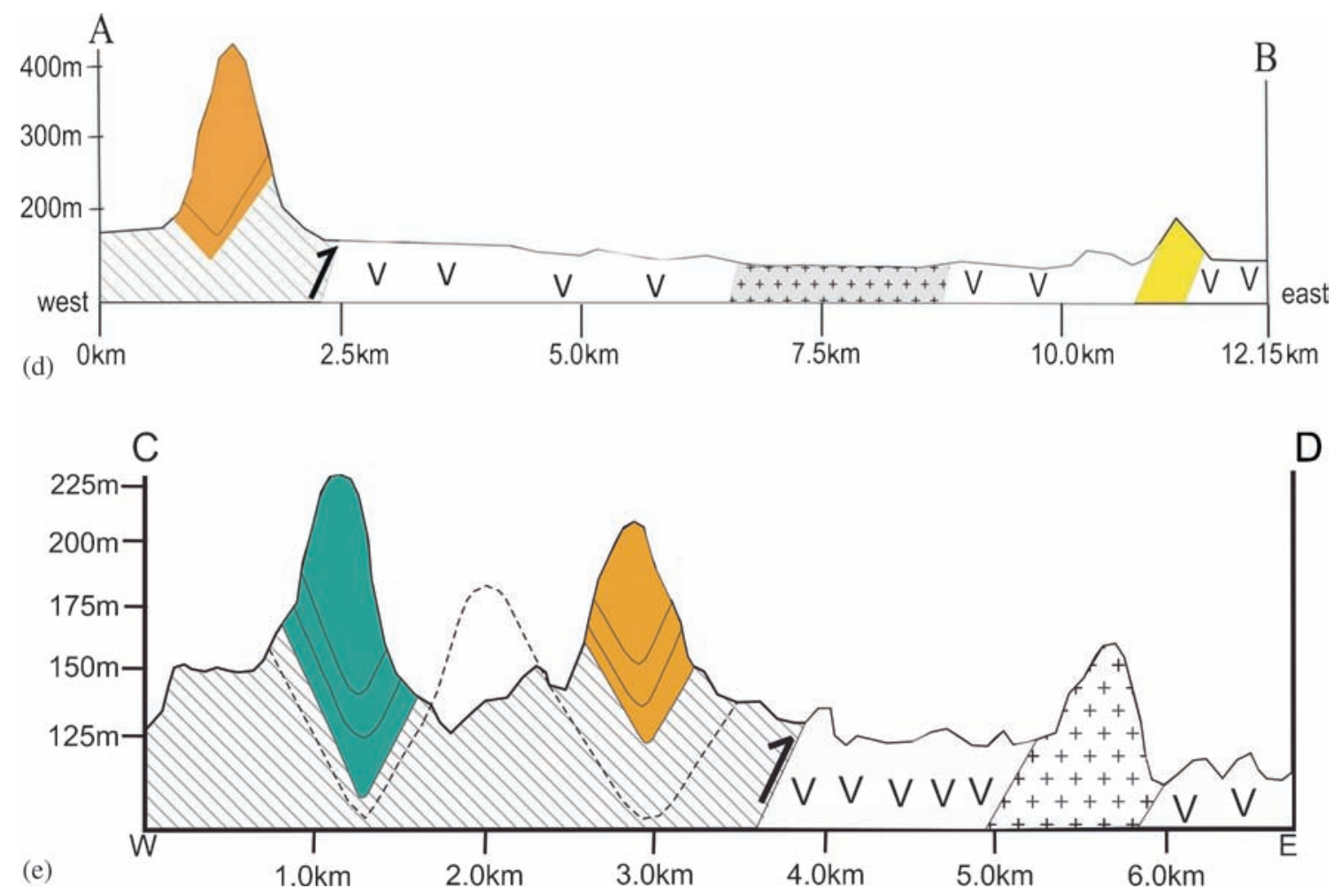

Figure 3. (Continued.)

contact, occurring nearly over a strike length of $35 \mathrm{~km}$ within the study area.

\subsection{Contact relationship between Udayagiri group and Vinjamuru group}

A detailed structural study reveals evidences of inclined transpression at the contact between Udayagiri and Vinjamuru groups. The contact is traceable from Nallamadgulla village $\left(15^{\circ} 09^{\prime} 04^{\prime \prime} \mathrm{N}\right.$; $79^{\circ} 15^{\prime} 30^{\prime \prime} \mathrm{E}$ ) in the north to Duttaluru village $\left(14^{\circ} 51^{\prime} 10^{\prime \prime} \mathrm{N} ; 79^{\circ} 24^{\prime} 20^{\prime \prime} \mathrm{E}\right)$ in the south. All along the contact, the S0/S1 schistosity as well as protomylonitic foliation in the rocks of both Udayagiri group as well as Vinjamuru group dips towards west. The structures (restricted to a narrow linear zone, i.e., 3-4 km on the both sides of the contact) are dealt by dividing it into two sectors, the northern sector and the southern sector.

The northern sector comprises part of the contact exposed from Nallamadgulla village $\left(15^{\circ} 09^{\prime} 04^{\prime \prime} \mathrm{N}\right.$; $\left.79^{\circ} 15^{\prime} 30^{\prime \prime} \mathrm{E}\right)$ in the north to Gandipalem village $\left(15^{\circ} 04^{\prime} 12^{\prime \prime} \mathrm{N} ; 79^{\circ} 17^{\prime} 18^{\prime \prime} \mathrm{E}\right)$ in the south.

\subsubsection{Footwall deformation (Vinjamuru group)}

The main lithologies are metabasalt, lit-par-lit injection migmatite, quartzite, and granite. Metabasalt is strongly schistose. At places (near Brahmanapalle village $15^{\circ} 03^{\prime} 54^{\prime \prime} \mathrm{N} ; 79^{\circ} 17^{\prime} 23^{\prime \prime} \mathrm{E}$ ), the schistosity of the schistose-metabasalt is seen to be swerving around some massive patches due to strain heterogeneity. Microscopic study also shows similar phenomenon, where slender prismatic grains of hornblende are found to be swerving around a sub-rounded basal section of hornblende grains (figure 4a). This type of strain heterogeneity is common in shear zones, where the strain is accumulated in narrow zones leaving undeformed parts in between forming shear lenses. A strong mineral elongation lineation is present in metabasalt defined by amphibole grains (hornblende) steeply plunging towards north (figure $4 \mathrm{~b}$ ) along with $\mathrm{C}^{\prime}$-type of shear bands (in the plan) showing a dextral sense of shearing. Under microscope also (thin section cut parallel to the mineral lineation) shear bands are present showing dextral, i.e., top towards east movement (figure 4c). Recrystallisation of hornblende grains is not observed, which suggest a low-temperature deformation, probably in a green schist facies condition. This suggests that the Vinjamuru group suffered amphibolite facies metamorphism before the non-coaxial deformation. The lit-par-lit injection migmatite and granite are intensely sheared and show $\mathrm{S}>\mathrm{L}$ and $\mathrm{L}>\mathrm{S}$ fabric respectively. The stretching lineation in granite (formed by stretched 

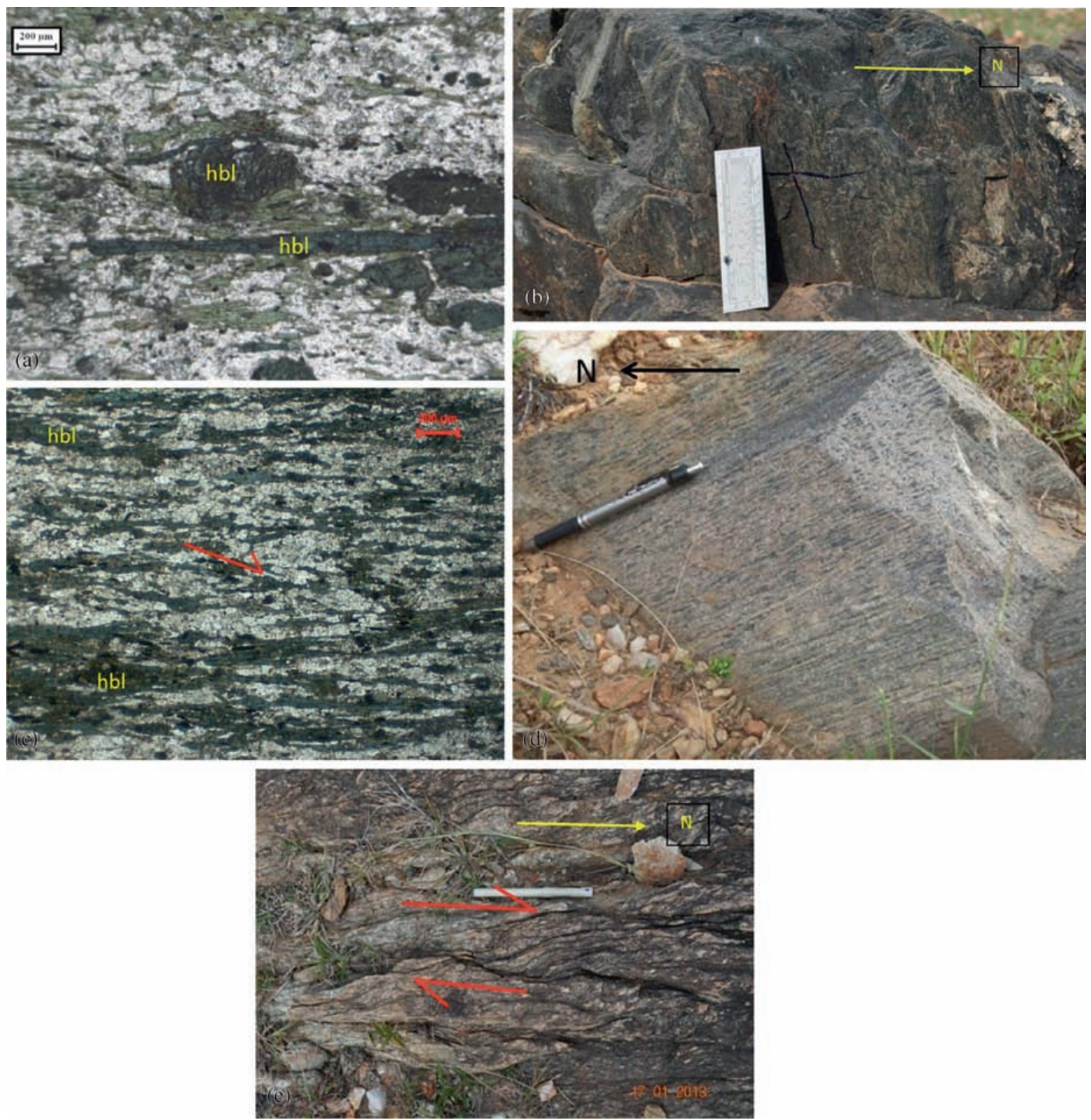

Figure 4. (a) Photomicrograph of schistose metabasalt (ppl) showing swerving of major schistosity defined by hornblende grains swerving around a grain of hornblende (basal section). Hbl=hornblende. (b) Mineral elongation lineation in metabasalt steeply plunging towards the north. (c) Photomicrograph of schistose metabasalt (X-Z section) shows shear band showing top towards east movement. (d) Stretching lineation in granite moderately plunging towards the north. (e) S-C fabric in sheared granite showing a dextral sense of movement (plan).

quartz grains and biotite) show moderate plunge towards the north (figure 4d). Lit-par-lit injection migmatite shows the development of steeply plunging sidewise closing intrafolial folds (suggesting dominance strike-slip component of non-coaxial deformation, Jones et al. 2004). C and C'-type of shear bands (in the plan) are common in both granite and lit-par-lit injection migmatite, showing a dextral sense of shearing (figures $4 \mathrm{e}$ and $5 \mathrm{a}$ ), suggesting right lateral strike-slip component. The orientations of the dextral shear bands are ranging between N25E to N45E. The intrusion of lit-par-lit injection within the Vinjamuru group occurred before the D1 phase of deformation because intrafolial (F1) folds are recorded within the migmatites. Microscopic study of the granite reveals the quartz grains are completely recrystallised and shows very fine grain size. The schistosity in granite defined by muscovite and recrystallised quartz grains swerve around porphyroclast of $\mathrm{K}$-feldspar (figure $5 \mathrm{~b}$ ). In thin section (cut parallel to the strike of the foliation), $\sigma$-shaped K-feldspar porphyroclast shows a dextral sense of shearing (figure 5c) with tails of muscovite and 

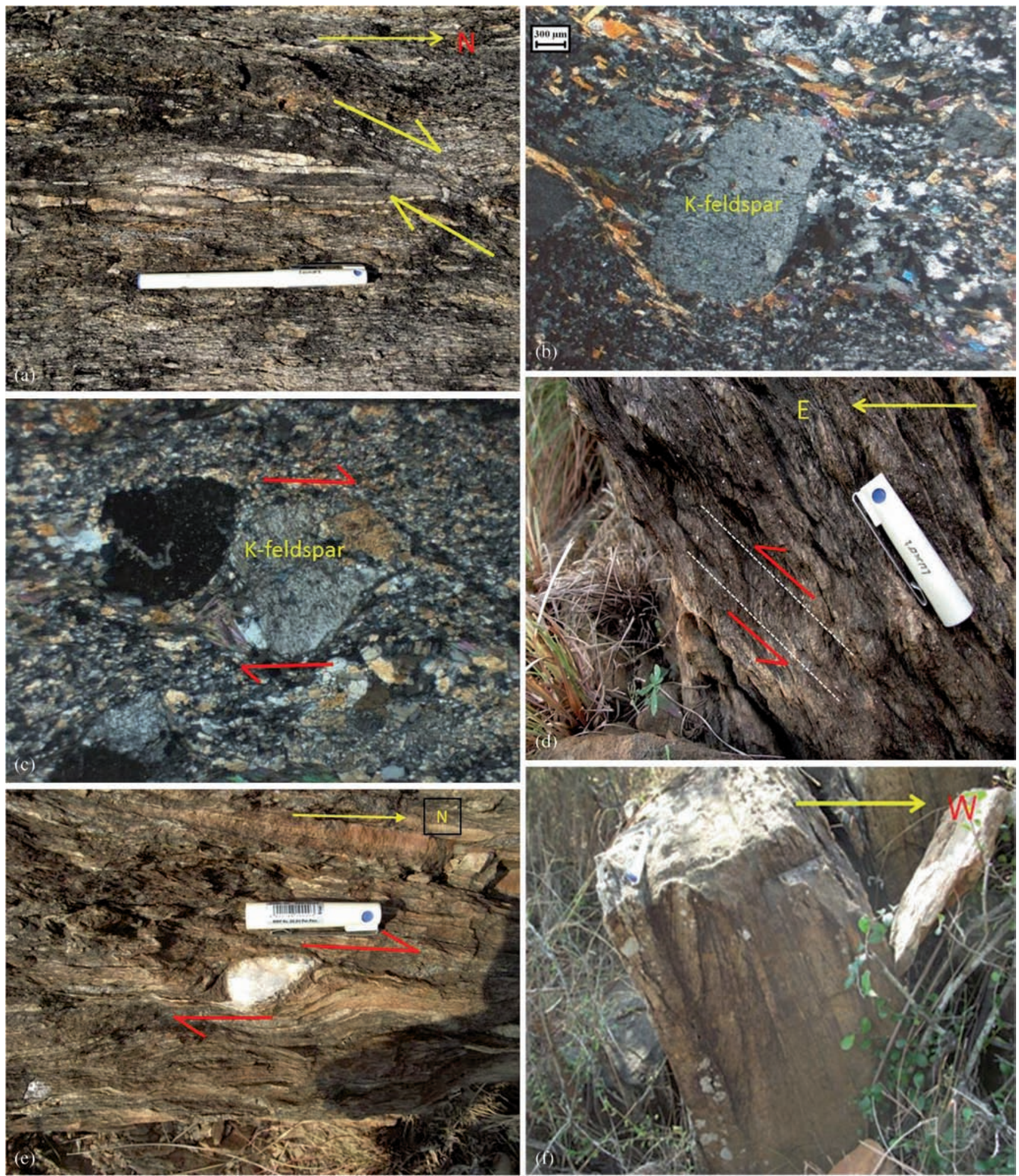

Figure 5. (a) Intrafolial folds and shear band in lit-par-lit injection migmatite showing a dextral sense of shearing. (b) Photomicrograph of swerving mylonitic foliation around K-feldspar porphyroclast in sheared granite. (c) Photomicrograph of $\sigma$-shaped K-feldspar porphyroclast shows dextral sense of shearing (Y-Z) section in sheared granite. (d) S-C fabric in metapelite of Udayagiri group showing top towards east movement (profile section). (e) Porphyroclast of quartz in metapelite of Udayagiri group showing dextral sense of movement (plan view). (f) Inverted beds in quartzite of Udayagiri group.

quartz suggesting low-temperature deformation of the granite (Paschier and Trouw 2005), supporting the green-schist facies metamorphic condition during non-coaxial deformation. The quartzite ridge exposed west of Kondyapalem village $\left(15^{\circ} 03^{\prime} 37^{\prime \prime} \mathrm{N}\right.$; $79^{\circ} 19^{\prime} 15^{\prime \prime} \mathrm{E}$ ) represents an overturned east-verging 
antiform as a whole (figure 2), suggesting top towards the east movement.

\subsubsection{Hangingwall deformation (Udayagiri group)}

The lithopackage includes quartzite, psammopelite and chloritoid-garnet schist. The contact follows the easternmost part of the Errakonda hill. All along this part psammopelite shows the development of tight, isoclinal, intrafolial F1 generation folds. The limbs of the folds (F1) are stretched and detached along the length and at some instances, only hinges of the folds are preserved as rootless folds showing class-1c geometry of Ramsay. At places, F1 folds are reclined in nature. Quartz veins, intruded parallel to S0/S1 (interfolial quartz veins) show strong boudinage in both strike parallel and perpendicular section, indicating flattening strain. A strong stretching/mineral elongation lineation is present in both quartzite and chloritoidgarnet schist respectively showing steep plunge towards north, suggesting a strike-slip component of non-coaxial deformation. Strong development of shear bands, sheared boudins and S-C fabric are seen at several places along the contact both in dip section and plan showing top towards east dipslip movement and right lateral strike-slip movement respectively (figure $5 \mathrm{~d}$ and e), although some sinistral sense shear bands $\left(\mathrm{C}^{\prime \prime}\right)$ are also present in strike parallel section. Inversion of beds is recorded in quartzite (figure 5f) (delineated from cross beds which show younging towards east but beds dip towards west), suggesting non-coaxial (dipslip) deformation giving rise to top towards the east movement. Thin section of chloritoid-garnet schist, cut parallel to the mineral elongation lineation $(\mathrm{X}-\mathrm{Z})$ show $\delta$ shaped porphyroclast of garnet (tails are made up of chlorite) showing a dextral sense of shearing, i.e., top towards east movement (figure 6a) and $\mathrm{C}$ and $\mathrm{C}^{\prime}$ type of shear bands (in thin section cut perpendicular to mineral lineation) show dextral sense of shearing, indicating right
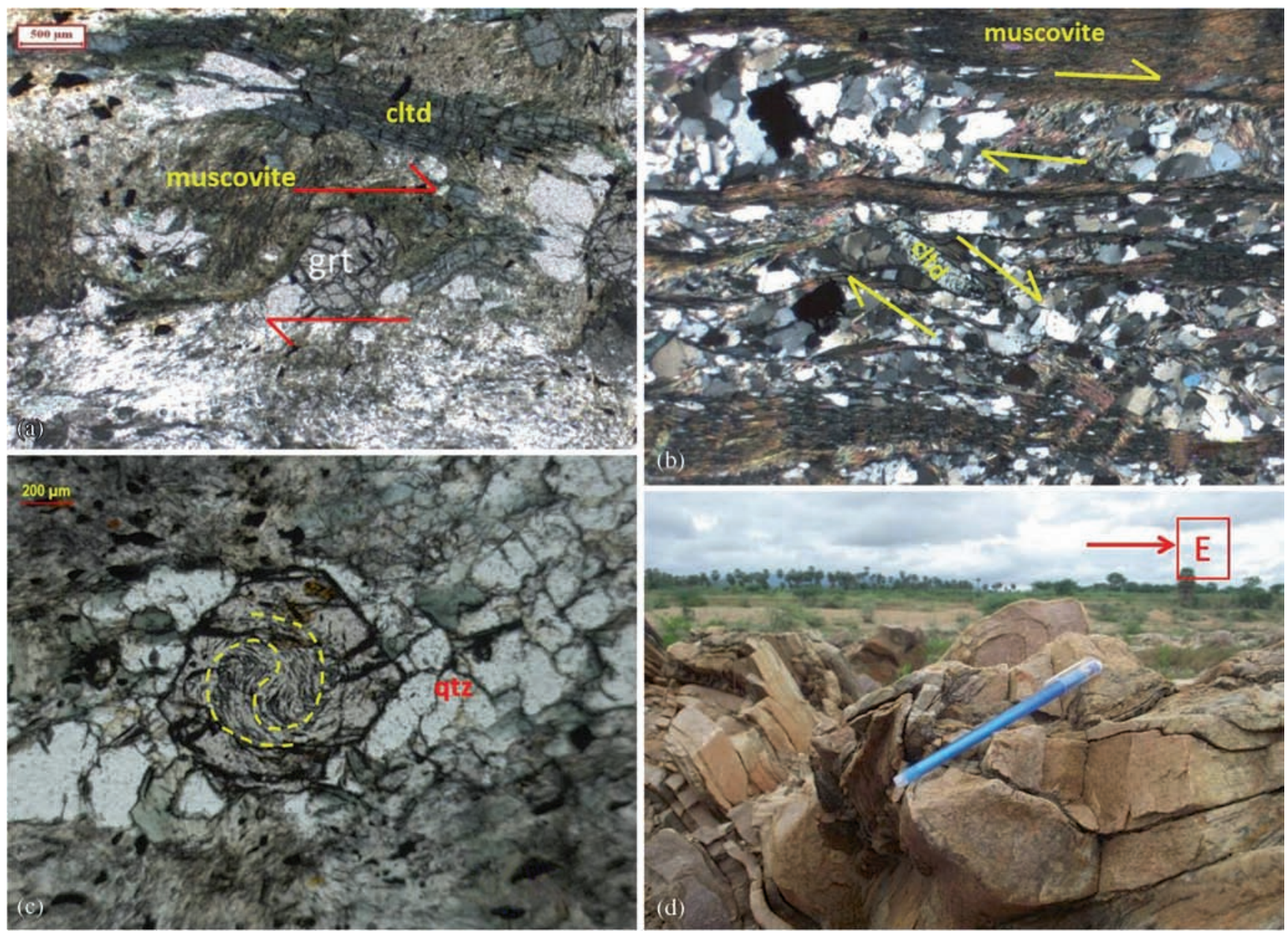

Figure 6. (a) Photomicrograph of syn-tectonic porphyroclast of garnet showing top towards east movement in strike perpendicular $\left(\mathrm{X}-\mathrm{Z}\right.$ ) section from chloritoid-garnet schist of Udayagiri group. grt=garnet. (b) Photomicrograph of $\mathrm{C}$ and $\mathrm{C}^{\prime}$ type of shear band showing dextral sense of shearing in strike parallel (Y-Z) section from chloritoid-garnet schist of Udayagiri group. Qtz=quartz, cltd=chloritoid. (c) Photomicrograph of Euhedral garnet grains with spiral inclusion trails preserved in core of the grain from chloritiod-garnet schist of Udayagiri group. (d) East verngent folds in schistose granite intruded within Vinjamuru group. 
lateral strike slip movement (figure 6b). Some of the porphyroblast of garnets show preservation of spiral inclusion trails inside the core of the grain, but the margins of the grain show euhedral shape (figure 6c) indicating rotation of syn-tectonic garnet grains under the influence of a strong noncoaxial deformation and continued growth of garnet grains after non-coaxial deformation. The margins of garnets are found to be altering to chlorite due to later retrogression. All the above evidences point towards a non-coaxial deformation in more than one reference coordinate axis along with a strong $\mathrm{E}-\mathrm{W}$ contraction (pure shear), which is responsible for the schistose nature of the rocks.

The southern sector of the contact starts from Gandipalem village $\left(14^{\circ} 59^{\prime} 56^{\prime \prime} \mathrm{N} ; 79^{\circ} 18^{\prime} 34^{\prime \prime} \mathrm{E}\right)$ in the north to Masayapetta village $\left(14^{\circ} 54^{\prime} 16^{\prime \prime} \mathrm{N}\right.$; $79^{\circ} 19^{\prime} 24^{\prime \prime} \mathrm{E}$ ) in the south.

\subsubsection{Footwall deformation (Vinjamuru group)}

The main lithotypes are metabasalt, granite and quartzite. The metabasalt and the quartzite show the same deformation characters mentioned above. The granite occurring east of Gandipalem reservoir is strongly foliated and lineated (showing strong L-S fabric). Foliation mostly dips towards west (except at some places it dips towards east due to F2 folding) and the stretching lineation (defined by elongated quartz and feldspar grains) shows steep plunge towards the north. The westerly dipping foliation shows east vergent asymmetric folds (figure 6d) stepped slickenside surfaces suggesting top towards east or NE movement. Thin section of this granite shows a well-defined foliation of biotite, quartz and amphibole grains. The quartz grains show undulate extinction but no recrystallisation of both quartz and feldspar grains.

\subsubsection{Hangingwall deformation (Udayagiri group)}

The main rock types are quartzite, psamopellite and chloritoid-garnet schist. Patches of the quartzpebble conglomerate are found near Gangireddipalle, Somalareggada $\left(14^{\circ} 51^{\prime} 39^{\prime \prime} \mathrm{N} ; \quad 79^{\circ} 22^{\prime} 03^{\prime \prime} \mathrm{E}\right)$ and Masayapetta village $\left(14^{\circ} 54^{\prime} 16^{\prime \prime} \mathrm{N} ; 79^{\circ} 19^{\prime} 24^{\prime \prime} \mathrm{E}\right)$ near
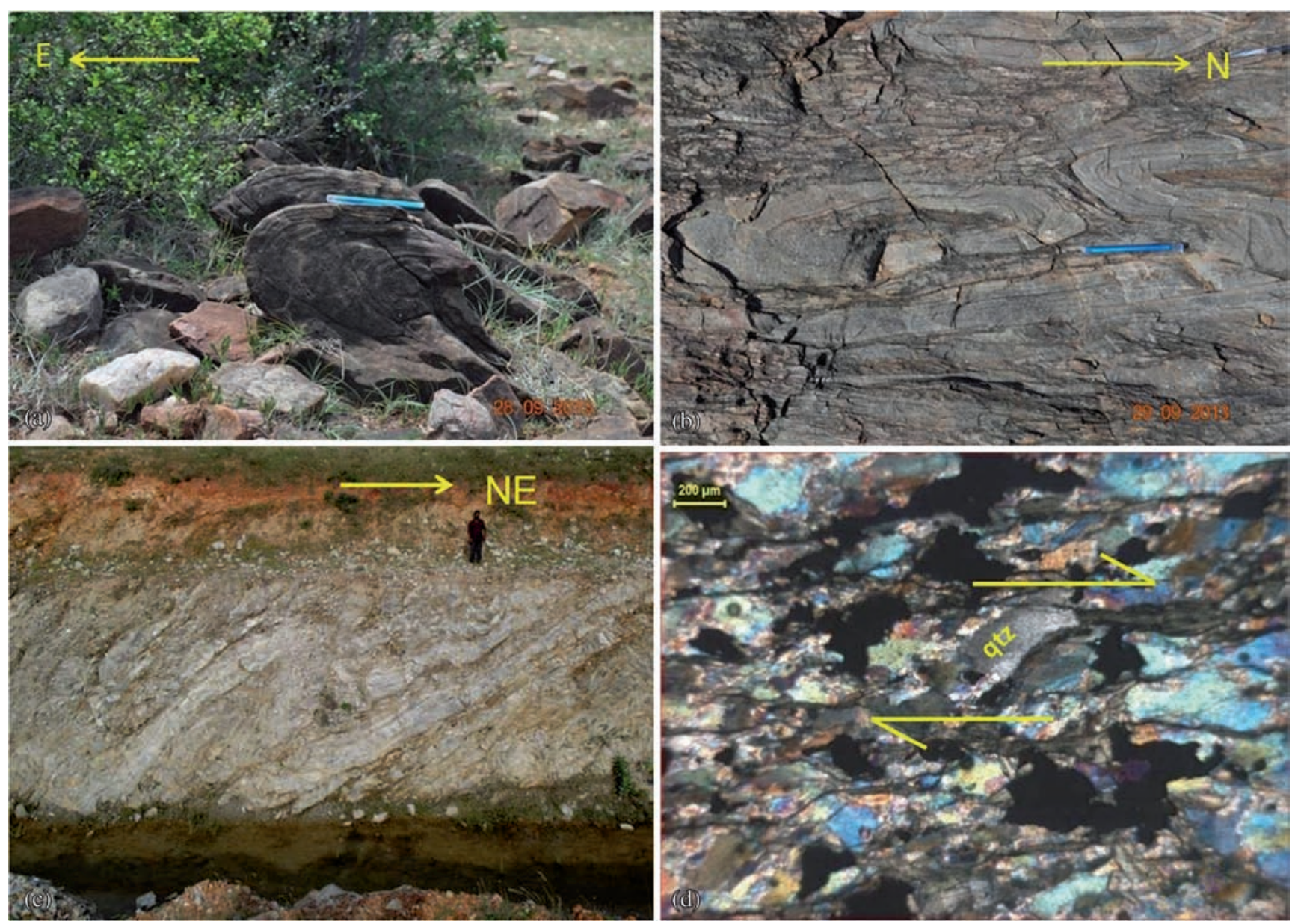

Figure 7. (a) Recumbent folds in quartzite (arkosic sandstone) of Udayagiri group. (b) Sheath folds in alternate phyllitequartzite sequence of Udayagiri group (plan). (c) Large-scale asymmetric east vergent fold in quartzite of Udayagiri group in a canal section. (d) Photomicrograph of S-C fabric in quartzite of Udayagiri group showing top towards east movement in strike perpendicular $(\mathrm{X}-\mathrm{Z})$ section. 
to the contact of Udayagiri and Vinjamuru groups. Quartz pebbles are rounded to subrounded in shape, set in an arkosic matrix and size varying from few $\mathrm{cm}$ to $15 \mathrm{~cm}$. The quartz pebbles are deformed with their long axis oriented down dip of the foliation, matching with the orientation of stretching/mineral elongation lineation so far described. Thrust related structures include recumbent folds, observed in thinly bedded quartzite with undulating (noncylindrical) hinge lines (figure 7a), indicating distributed shearing (Ghosh and Saha 2005), sheath folds within thinly bedded quartzite (figure $7 \mathrm{~b}$ ), and huge overturned NW-SE trending, shallow plunging NE vergent folds (amplitudes of 2-3 m) with thicker and shorter steep limb (figure 7c). These kinds of asymmetric folds are found in sequences with lower competency contrast and high amount of simple shear (Mukherjee 2001). Sheath folds are developed in transpressional zones where the bulk strain is of flattening type and the initial angle between fold axis/vorticity vector and stretching lineation is high and the fold axis rotates towards the stretching lineation in due course of deformation (Sengupta and Ghosh 2004). Such zones fall in group-VI of Sengupta and Ghosh (2004). A small patch of schistose metabasalt of Vinjamuru group occurs as tectonic sliver within the metasediments (NW of Gangireddipalle village) also registers similar kind of deformation. Microscopic study of quartzite (occurring west of Kondareddipalle village) reveals the presence of $\mathrm{S}-\mathrm{C}$ fabric in strike perpendicular (XZ) section showing top towards east movement (figure $7 \mathrm{~d}$ ), but no recrystallization of quartz grains. From the above discussion, it is evident that similar type of deformation pattern is observed in both hanging wall and footwall rocks suggesting non-coaxial deformation in more than one reference coordinate axis (both dip-slip and strike-slip) along with an E-W pure shear component.

Both the northern and southern sectors show similar patterns of deformation, except that southern sector shows more structures related to dip-slip component of non-coaxial deformation relative to the strike-slip component.

Stereographic projection of stretching lineation data in stereonet collected from the whole contact zone shows a clockwise shift from its orthogonal position (figure $8 \mathrm{a}$ and $\mathrm{b}$ ), suggesting $\mathrm{a}$ right-lateral sense of strike-slip movement. At few places stretching lineation are found to be plunging towards the south, may be due to a local change in strike-slip direction and stereographic plots of these stretching lineation data on stereonet show anticlockwise shift from the orthogonal position (figure $8 \mathrm{a}$ and $\mathrm{b}$ ). Variation of the pitch of the stretching lineation along the zone indicates triclinic strain symmetry (Jones et al. 2004).
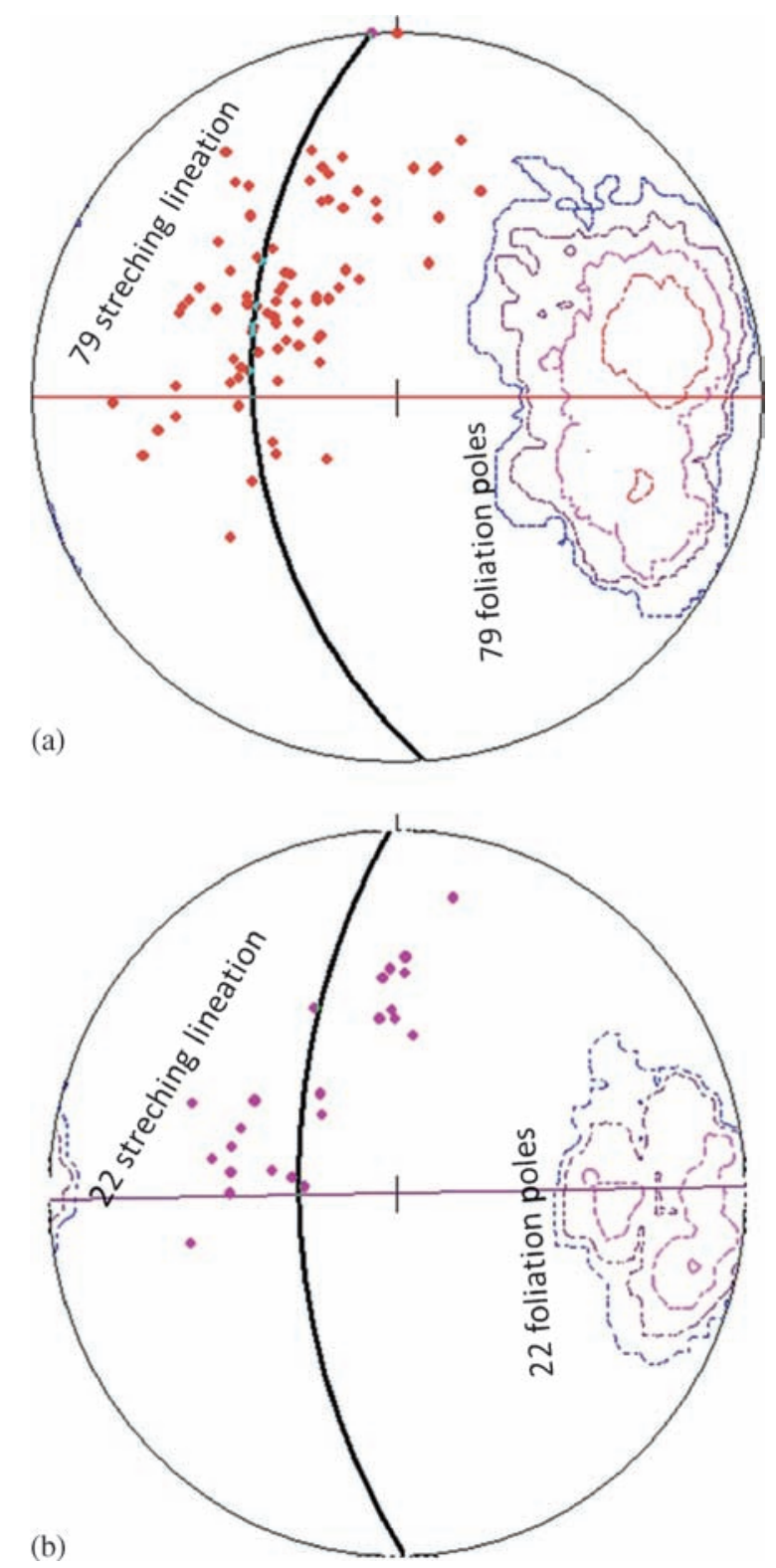

Figure 8. (a) Lower hemisphere plots of pitch stretching lineation (pink dots) of both Udayagiri group and Vinjamuru group. Most of the stretching lineation show a shift from orthogonal position plunge towards the north. (b) Lower hemisphere plots of pitch stretching lineation (pink dots) of granite intruded within Vinjamuru group. Most of the stretching lineation show a shift from orthogonal position and plunge towards the north.

\section{Discussion}

In the case of oblique thrusting, non-coaxial deformation in more than one reference coordinate axis is possible, which will give rise to shear related fabric in both strike parallel and perpendicular section. But only oblique thrusting (simple shear) should give rise to plane strain $(K=1)$ deformation. In the present case, along with non-coaxial deformation, evidences of flattening strain are also present, such as development of class-1c type (flattened folds) (Ramsay 
1967) intrafolial folds along the contact, presence of boudinage in both strike parallel and perpendicular section, presence of sheath folds (Sengupta and Ghosh 2004) and measurement of three axes of the Quartz pebbles (from the quartz-pebble conglomerate occurring near Gangireddipalle, Somalareggada village) fall in apparent flattening field with an average $K$ value of 0.398 when plotted in Flinn diagram (figure 9a). But constrictional strain is also recorded near the contact between two groups, near the SE corner of the study area (not mapped), located nearly $10 \mathrm{~km}$ SE of Masayapetta village $\left(14^{\circ} 54^{\prime} 16^{\prime \prime} \mathrm{N} ; 79^{\circ} 19^{\prime} 24^{\prime \prime} \mathrm{E}\right)$ and west of Duttaluru village $\left(14^{\circ} 51^{\prime} 10^{\prime \prime} \mathrm{N} ; 79^{\circ} 24^{\prime} 20^{\prime \prime} \mathrm{E}\right)$, where the trend of the contact takes a swing from its general NNW-SSE trend and become nearly E-W. Here steep southerly plunging cigar shaped quartz roddings (figure $9 \mathrm{~b}$ ) are recorded in quartzite of Udayagiri group. Lin and Jiang (2001), pointed out that constrictional strain can also be recorded in curved transpressional shear zones where $\alpha$ (the

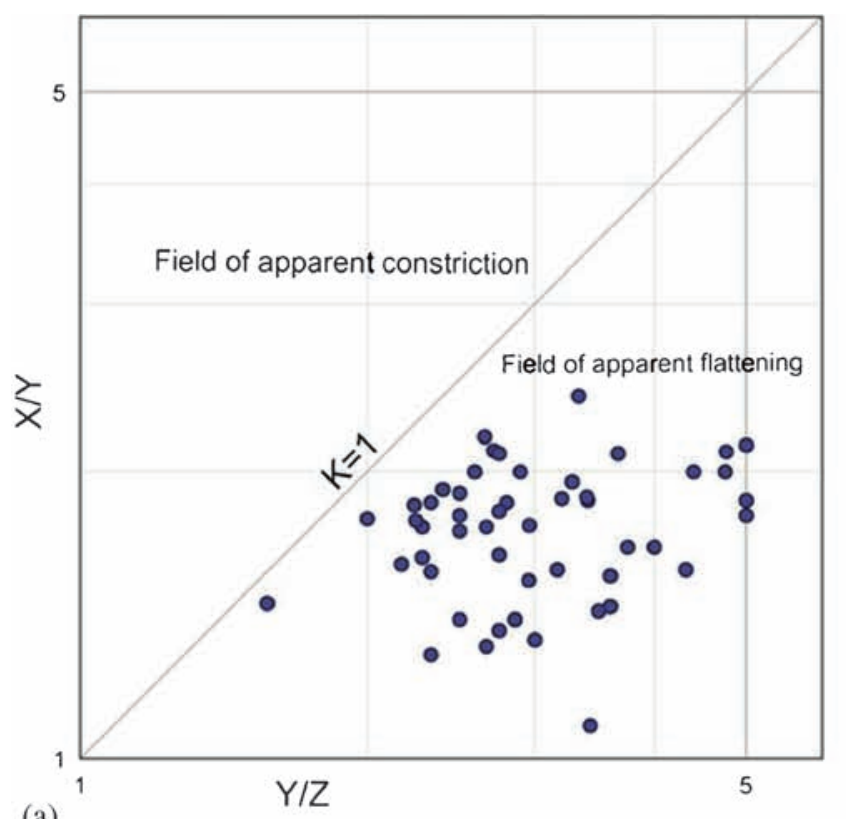

(a)

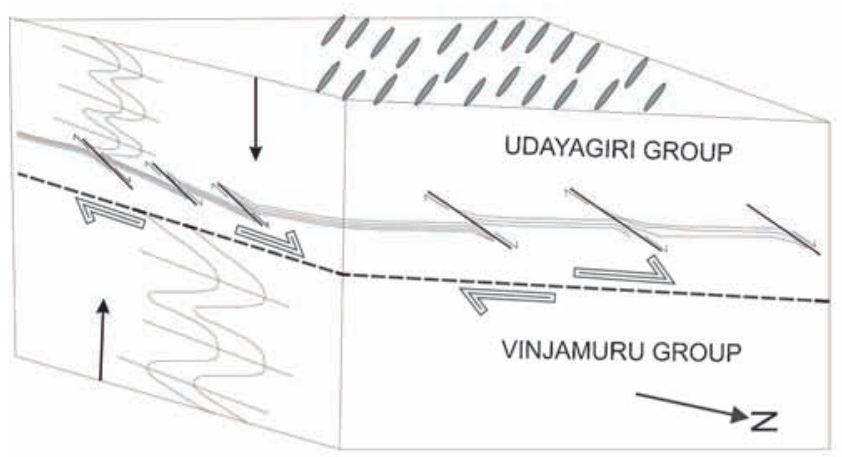

(c) angle between movement direction and trend of shear zone) becomes very low, and is applicable to the present case, because the contact becomes $\mathrm{E}-\mathrm{W}$, i.e., parallel to direction of contraction (pure shear). So from the above discussion, it is evident that the contact between the Udayagiri group and the Vinjamuru group can be better explained by inclined transpression model. The strain in the contact zone is partitioned into a strike-slip and dipslip component along with a simultaneous $\mathrm{E}-\mathrm{W}$ shortening (figure 9c). The strike-slip component shows right-lateral sense of movement and the dipslip component show top towards east movement, evident from several shear sense indicators ranging from a mesoscopic to microscopic scale, discussed so far. The E-W contraction is considered simultaneous with shearing (D1 stage of deformation) because of (i) development of intrafolial folds with development of strong S1 cleavage/schistosity, especially in phyllie but sometimes also in thinly laminated quartzites which suggest a significant

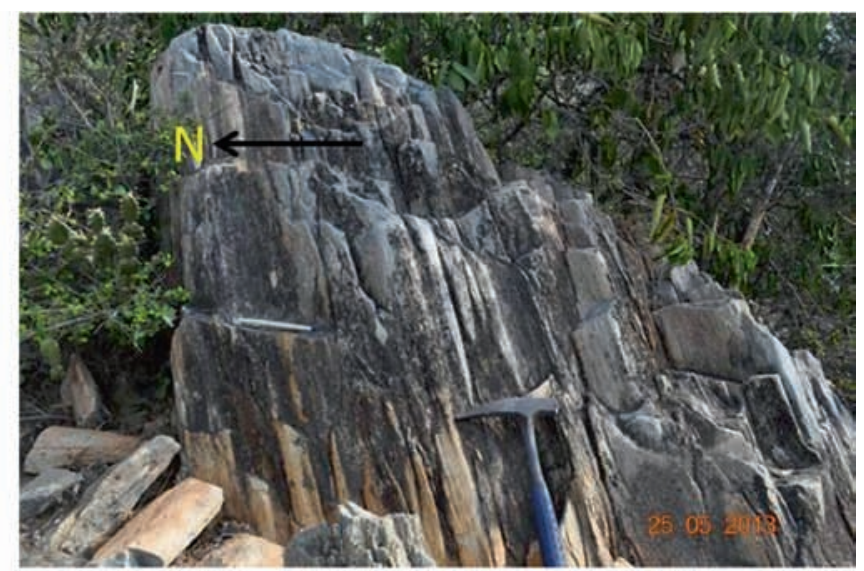

(b)

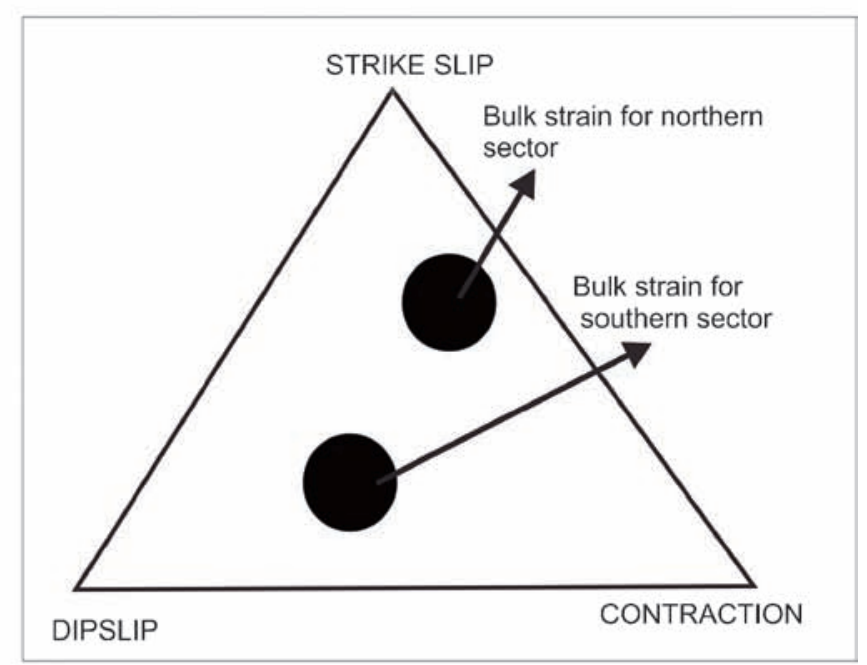

(d)

Figure 9. (a) Plot of pebble axes in Flinn Diagram. (b) Quartz roddings in quartzite of Udayagiri group. (c) Model of transpression. (d) Plots of bulk strain for the study area in strain triangle after Jones et al. (2004). 
amount of shortening (Saha et al. 2010) during D1 phase of deformation, (ii) quartz microfabrics show deformation in crystal plastic regime, which is not found in D2 or later deformational event (Saha et al. 2010). However, D2 stage of deformation might have the same FSE (finite strain ellipsoid) as the D1 phase of deformation, which is delineated by crenulation of mylonitic foliation (Saha et al. 2010). But an entirely different geometry of F1 and F2 folds suggest their development in two different stages.

\section{Conclusion}

From the above discussion, it is evident that the strain is heterogeneous along the contact of the two groups. In the northern sector, the F1 folds are mostly sidewise closing, tight isoclinal in nature, suggesting a sub-vertical vorticity vector and dominance of strike-slip component of noncoaxial deformation (Jones et al. 2004), than the dip-slip component, along with a pure shear component (contraction) defined by a strong development of S1 schistosity. So the bulk strain for the northern sector will fall near the center of the strain triangle defined by Jones et al. (2004) (figure 9d). The southern sector on the other hand, is dominated by the development of strong schistosity with frequently occurring shallow plunging eastverging asymmetric folds in both hanging wall and footwall, suggesting a sub-horizontal vorticity vector and dominance of dip-slip component of noncoaxial deformation and contraction (pure shear) respectively (Jones et al. 2004). So the bulk strain for the southern sector will fall near the basal edge of the strain triangle defined by Jones et al. (2004) (figure 9d).

Structures related to the thrusting of Udayagiri group over Vinjamuru group are restricted to a narrow linear zone, i.e., $3-4 \mathrm{~km}$ on both sides of the contact. So during the D1 stage of deformation, the Udayagiri group got thrusted over Vinjamuru group along a westerly dipping thrust plane. After that the thrust plane got folded due to D2 stage of deformation and gave rise to map scale alternate antiforms and synforms (F2 folds). This suggests that the sediments of Udayagiri group were deposited somewhere else after which it travelled towards east due to a force from the west and got juxtaposed against Vinjamuru group leading to a westerly dipping thrusted contact. Limited $\mathrm{P}-\mathrm{T}$ estimates by the present authors (Das et al. 2013) give highest temperature estimate within a range of $398^{\circ}-440^{\circ} \mathrm{C}$ from the metapelites of Udayagiri group. Whereas temperature estimates from garnet-bearing metabasalt of Vinjamuru group give a temperature range of $540^{\circ}-600^{\circ} \mathrm{C}$ and pressure estimate of 5.9-6.3 kb. Moeen (1998) estimated a temperature range of $715^{\circ}-765^{\circ} \mathrm{C}$ and pressure range of $8.6-9.2 \mathrm{~kb}$ for the $\mathrm{M} 1$ phase of metamorphism and a temperature range of $520^{\circ}-$ $570^{\circ} \mathrm{C}$ and pressure range from $6.1-6.8 \mathrm{~kb}$ for the M2 phase of metamorphism from the metapelites of Vinjamuru group. This thrusted contact also explains the sudden increase of metamorphic grade from Udayagiri group (greenschist facies) to Vinjamuru group (amphibolite facies) across the contact. After this phase the whole Nellore Schist Belt (formed due to amalgamation of Udayagiri group and Vinjamuru group) was later thrusted over Nallamalai fold belt (NFB) during $1500 \mathrm{Ma}$ (Saha 2004) along an easterly-dipping thrust plane and at later phase (1000 Ma, Saha 2004) EGMB got thrusted over the NSB.

\section{Acknowledgements}

The authors thank the Director General of Geological Survey of India for permitting to publish the paper. They express their deep sense of gratitude to Shri S Balakrishnan, Deputy Director General (retired), Southern Region, and Shri M S Jairam, Deputy Director General, State Unit: Andhra Pradesh (retired) for their co-operation and constant encouragement without which this investigation would not have been possible. The authors express their sincere gratitude towards Dr Nibir Mandal for his constructive review and necessary suggestions, which improved the quality of the manuscript.

\section{References}

Das S, Shukla D and Mitra S K 2013 Pressure-temperature estimates from the rocks of Vinjamuru group and Udaigiri group of Nellore Schist Belt (NSB), Pamuru Area, Prakasam District, Andhra Pradesh; National Conference on Earth Sciences in India: Challenges and Emerging Trends (ESICET-2013).

Dobmeier Cristoph J and Raith Michael M 2003 Crustal architecture and evolution of the eastern Ghat belts of adjacent regions of India; Geol. Soc. London Spec. Publ. 206 145-168.

Fossen H and Tikoff B 1993 The deformation matrix for simultaneous simple shearing, pure shearing, and volume change, and its application to transpression/transtension tectonics; J. Struct. Geol. 15 413-422.

Fossen H and Tikoff B 1998 Extended models of transpression and transtension, and application to tectonic settings; Geol. Soc. London Spec. Publ. 135 15-33.

Ghosh G and Saha D 2005 Kinematics of large scale asymmetric folds and associated smaller scale brittleductile structures in the Proterozoic Somnur Formation, Pranhita-Godavari Valley, south India; J. Earth Syst. Sci. 114 125-142.

Hari Prasad B, Okudaira T, Divi R S and Masaru Y 1999 Structural features of the Archean Nellore-Khammam Schist Belt, southeast India; J. Geosci. 42 227-235. 
Harland W B 1971 Tectonic transpression in Caledonian Spitsbergen; Geol. Mag. 108 27-32.

Jones R R, Holdsworth R E, Clegg P, McCaffrey K and Tavarnelli E 2004 Inclined transpression; J. Struct. Geol. 26 1531-1548.

Lin Soufa and Jiang Dazhi 2001 Using along strike variation in strain and kinematics to define the movement direction in curved transpressional shear zones: An example from NW Superior province, Manitoba; Geol. 29 767770 .

Moeen S 1998 P-T estimates from the Nellore schist belt (India) and evidence for the superimposed metamorphic events; Geol. J. 33 1-15.

Mukherjee M K 2001 Structural pattern and kinematic framework of deformation in the southern Nallamalai fold-fault belt, Cuddapah district, Andhra Pradesh, southern India; J. Asian Earth Sci. 19 1-15.

Narayana Rao M 1983 Lithostratigraphy of the Precambrian rocks of the Nellore Schist Belt; Quart. J. Geol. Mining Metallur. Soc. India 55 83-89.

Paschier W C and Trouw R A J 2005 Microtectonics; Springer-Verlag, Berlin Heidelberg, Germany.

Ramam P K and Murty V N 1997 Geology of Andhra Pradesh; Geological Society of India, Bangalore, 245p.

Ramsay J G 1967 Folding and fracturing of rocks; McGrawHill, New York.

Ravikant V 2010 Palaeoproterozoic (1.9 Ga) extension and breakup along the eastern margin of the Eastern Dharwar Craton, SE India: New Sm-Nd isochron age constraints from anorogenic mafic magmatism in the Neoarchean Nellore greenstone belt; J. Asian Earth Sci. 12 67-81.

Saha D 2004 Structural asymmetry and plate tectonic setup for a Proterozoic fold and thrust belt: Nallamalai fold belt and adjoining terrane, south India; Geol. Surv. India Spec. Publ. 84 101-119.

Saha D, Chakraborti S and Tripathy V 2010 Intracontinental thrusts and inclined transpression along eastern margin of the East Dharwar Craton, India; J. Geol. Soc. India $75323-337$.

Saha D, Sain A, Nandi P, Mazumder R and Kar R 2013 Tectonostratigraphic evolution of the Nellore schist belt, southern India, since the Neoarchaean, In: Precambrian Basins of India: Stratigraphic and Tectonic Context (eds) Pat Eriksson and Rajat Mazumder, Geological Society London Memoir.

Sanderson David J and Marchini W R D 1984 Transpression; J. Struct. Geol. 6 449-458.

Sengupta S and Ghosh S 2004 Analysis of transpressional deformation from geometrical evolution of mesoscopic structures from Phulad shear zone; J. Struct. Geol. 26 1961-1976.

Srinivasan K N and Roop Kumar D 1995 Geological mapping of Podili-Kanigiri section in northern part of Nellore schist belt, Prakasam district, AP, Unpublished Progress Report Geol. Surv. India, FS 1992-93.

Suresh G, Bhattacharjee S and Narahari S T 2006 Report on detailed Petro-mineralogical studies of Nellore schist belt and cuddapah cover rocks; Unpublished report of Geological Survey of India.

Vasudevan D and Rao T M 1975 The high grade schistose rocks of Nellore Schist Belt, Andhra Pradesh and their geologic evolution; Indian Mineral. 16 43-47.

Vasudevan D, Kota Reddy C and Rao T M 1975-76 Systematic geological mapping in parts of Udayagiri Taluk, Nellore District, Andhra Pradesh, Progress Report for the Field Season, Geological Survey of India. 